\title{
Em direção a uma 'Europa do Mundo' unida: entrevista com a historiadora Raquel Varela
}

Towards a United 'World's Europe': Interview with Historian Raquel Varela

Sara de Athouguia Filipe' (iD 0000-0002-8269-5859

'European University Institute, Firenze, FI, Itália. 50139 FIRENZE - servac@eui.eu

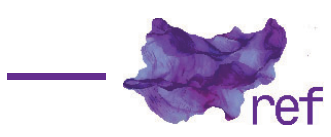

Raquel Cardeira Varela é historiadora, investigadora e professora universitária portuguesa, especializada na área da História do Trabalho, História do Movimento Operário e História Global. Coordenou e publicou mais de 25 livros nesta área, bem como dezenas de artigos publicados nos campos da Sociologia, Serviço Social e Ciência Política. A interdisciplinaridade e internacionalização de sua carreira acadêmica levaram-na a dar mais de 200 palestras realizadas em mais de 50 instituições portuguesas e estrangeiras. É membro convidado do Board of Trustees of the ITH - International Conference of Labour and Social History (Áustria), a mais antiga associação de estudos do trabalho na Europa, e membro da European Network in Universal and Global History (ENIUGH). Atualmente, é presidente da International Association Strikes and Social Conflicts, uma rede que conta com 35 instituições da Europa do Norte e Sul, Estados Unidos da América e América Latina. É coordenadora de vários projetos nacionais e internacionais com visibilidade e reconhecimento público, tendo recebido, em 2013, o Santander Prize for Internationalization of Scientific Production. Raquel Cardeira Varela é comentadora do programa semanal de debate público "O Último Apaga a Luz", na Rádio e Televisão de Portugal, e participa ativamente em outros espaços públicos proporcionados pela mídia.

$\mathrm{Na}$ entrevista que nos foi concedida, Raquel Cardeira Varela nos fala enquanto mulher, historiadora, acadêmica e, também, enquanto pensadora dos grandes problemas com que as mulheres e os homens de hoje se deparam - enquanto pessoas, trabalhadores, eleitores e cidadãos; de Portugal para a Europa e da Europa para o Mundo.

Sara de Athouguia Filipe: Seu último livro, Breve História da Europa (Raquel VARELA, 2018), que foca as transformações pelas quais passou o velho continente - no século XX -, é dedicado aos seus pais, que considera serem os primeiros historiadores da sua vida. De que forma a Europa, ou 'as Europas', que eles lhe mostraram, influenciaram o seu pensamento e interesses enquanto uma historiadora profissional?

Raquel Cardeira Varela: É difícil... É um bocadinho de psicanálise, não é? Eu tenho dificuldade em dar uma resposta a isso. Porque nós temos uma relação muito emocional com o nosso passado. Os meus pais são da geração de '68 - são cientistas da natureza, formados na década de '60 - e têm a perspectiva da totalidade; hoje é difícil encontrar um engenheiro que seja um crítico social também; em geral, sabem muito de pouco, mas os meus pais são da geração da totalidade, porque os cursos eram mais densos e a formação política juntava-se à técnica, dando uma noção de totalidade que hoje existe pouco - beneficiei muito de tudo isso, sou uma privilegiada. Eles são - os dois - engenheiros florestais que nos ensinavam história, que nos ensinavam geografia, que nos ensinavam cartografia. Que nos ensinam ciências naturais e sociais. Muito engajados politicamente, sobretudo ele, um dirigente marxista então (meio anarquista, meio maoísta e ainda meio socialdemocrata) [risos], em um momento de grandes transformações. Ela é genial, esta semana veio da Argélia, onde tem uma missão científica, e foi com os 4 netos para Londres ensinar-lhes a latitude e longitude, ida ao National Theatre, vão a 
Greenwich - antes de partirem trouxe a bola de pilates e desenhou na bola os meridianos aos 4 netos. Escolheu levá-los lá porque quer prestar homenagem ao Assange em nome de liberdade. Essa mulher extraordinária é a minha mãe, aos 68 anos.

Eles eram ambos muito apaixonados pela ideia de Europa-celebraram, com imenso entusiasmo, o fim do isolamento de Portugal na Europa com uma viagem pela Europa conosco, comigo e com o meu irmão, de carro, quando Portugal entrou para a CEE. Fizemos acho que 7 países de carro, para eles foi um grito de liberdade, o fim da autarcia, para nós foi abrir os horizontes do mundo, do outro, do que é diferente. Talvez as pessoas no Brasil façam uma ideia distinta. Mas a ideia de Europa - comunicada por transportes, sabedora do que se passa para além das fronteiras e interessada no destino comum de seus cocontinentais -, não é muito antiga no país. E meus pais viveram a transição, que é dos anos 80 . Eles gostavam de experimentar as comidas, as culturas, as músicas - tudo!

Ainda hoje eu passo férias percorrendo as estradas secundárias da Europa que têm mais História e cultura que algumas grandes metrópoles periféricas - numa pequena aldeia magnífica, no meio dos Pirenéus, há uma homenagem aos Maquis, da resistência, enterrados; noutra, da França, temos 200 habitantes e uma igreja do tamanho de uma catedral... Ou seja, as aldeias e as pequenas terras na Europa têm muita História; às vezes, as pessoas têm dificuldade em perceber isso, mas nem todos os lugares do mundo têm a riqueza da História europeia. Porque não há, na História da Humanidade, nenhum exemplo de tanto desenvolvimento (e de tanta destruição), tanta, em suma, História concentrada no tempo como o período do desenvolvimento do capitalismo na Europa. Quer do ponto de vista do desenvolvimento das forças produtivas, quer do ponto de vista da destruição delas, que é o caso da Segunda Guerra Mundial. Aqui o significado da História ganha realmente outra dimensão. Há mais História nesta história. Não é que não haja História noutros povos, obviamente que há e desafiadora de compreender, mas há mais História condensada na Velha Europa. Há mais contradição também. A Humanidade chegou mais perto do que são suas grandezas e as suas misérias na Europa do que em qualquer outro espaço-tempo global.

SAF: Não se ouve muitas vezes isso na Academia; hoje em dia, os debates tendem a explorar se determinados fenómenos terão sido ou não exclusivamente europeus...

RCV: Não. Nós passámos do eurocentrismo ao identitarismo e ao tribalismo localista e isso nega a ideia de processo e de progresso. Quantos milhares e milhões de brasileiros votam no Bolsonaro que são mulheres, negros e até pobres? E quantos fora do Brasil estão a torcer contra o Bolsonaro? Trump não chegou ao poder por acaso... A derrota das Primaveras Árabes e a resignação dos novos partidos como o Podemos, Syrisa ou a Geringonça, em Portugal, incapazes de resolver qualquer questão de fundo, pagaram um preço alto. O protecionismo não é só uma guerra comercial; o internacionalismo está ameaçado e a esquerda perdida, sem rumo - quer porque os problemas são tantos e os quadros dirigentes poucos, quer porque tem falta de sustentação teórica e medo da marginalidade - e respondeu a isso com uma agenda cada vez mais marginal. Veja: um programa de esquerda fala mais de famílias gays do que das famílias no seu conjunto, gays ou não. Creches, horários de trabalho, pagar contas básicas como alimentação, habitação, tempo para os filhos, educar filhos na família nuclear em sociedade urbana, isso são temas comuns a gays e a não gays, no entanto, todo o discurso é voltado para as minorias; como podemos governar assim?

Veja, no caso do feminismo dominante, por exemplo, é particularmente... interessante... perceber isto: a maioria das pessoas que morreram a defender direitos sociais na humanidade são homens heterossexuais, brancos e, provavelmente, machistas. Quem é que constrói os sindicatos que lutam por direitos elementares, como o é o direito ao voto? Na Inglaterra, o Cartismo, no século XIX, quando foram presos e mortos em massa. O que é que é a Revolução Russa? Tem uma participação importantíssima de mulheres - e homens como o são Lenin e Trotsky são os primeiros a reconhecê-lo; presto aqui homenagem a Kollontai - mas a maioria das pessoas que morreram na Primeira Guerra Mundial - e na luta contra a Guerra Mundial e que dirigiram a revolução russa, são homens. De repente, desapareceu a luta de classes e ficámos com a guerra dos sexos.

Sobre o eurocentrismo. Deixe-me voltar lá. O Marxismo, que é o que eu penso ser o nosso melhor instrumental para olhar para a História - não é psicanálise sobre o passado. Agora parece que os Europeus se têm de andar a chicotear num mea culpa judaico-cristão pelo seu passado. Primeiro, eu não andei a colonizar ninguém. Nasci há trinta e nove anos. O meu passado não tem nenhuma ligação - direta - com esta barbárie.

Segundo, as sociedades são divididas: a Europa tanto é o continente de Hitler quanto a Europa da Resistência ao Hitler, houve 300 mil alemães presos e mortos a lutar contra o Hitler; Franco, na revolução espanhola, apoiou-se nos marroquinos para derrotar tropas espanholas e inglesas. Portanto não há só alemães; há vários alemães. 
Quando comecei, apaixonada, a estudar o que é a História Global do Trabalho - finalmente nós tínhamos uma visão internacionalista, o desenvolvimento desigual e combinado do Trotsky tinha chegado à Academia, ainda que pela mão da História Global do Trabalho, pelo Marcel van der Linden, que tanto admiro, portanto, de uma forma mediada - e, de repente, parecia que só havia um inimigo: o sindicalista branco europeu, o que é, relativamente, um absurdo!, porque nunca morreu tanta gente na história da humanidade a lutar por direitos como o sindicalista branco europeu. Que era machista, era; a nossa vida é assim, vamos precisar de 400 anos de socialismo para entrar na história e assistir à igualdade plena. Talvez 200, sejamos otimistas, eu sou! Se calhar, a minha avó era mais machista do que esses homens, e por quê? Porque a minha avó nasceu num determinado contexto efetivo em que ela era uma dona de casa e era trabalhadora doméstica (uma das minhas avós, a outra era uma trabalhadora, pequena proprietária agrícola, é diferente). Ela não deixa de ser uma mulher maravilhosa, mas ela é uma mulher da sua hora. Com marcas de seu lugar.

A História não é um tribunal de justiça, não é um divã de psicanálise.

Uma coisa é nós nos colocarmos e defendermos um lado, outra é fazermos julgamentos anacrónicos sobre a História. A colonização é pura barbárie social, mas também foi desenvolvimento técnico. Nós reivindicamos isto ou aquilo? Não! Não se muda o passado, muda-se o futuro. É, aliás, para isso que serve a história. Oliver Sachs, famoso neurologista, tinha um paciente que tinha perdido a memória dos últimos 30 anos e não conseguia recordar-se de nada desde há poucos minutos, a sua vida não tinha interesse algum, porque sem memória ele também não tinha futuro. Não interessava viver no passado, mas era necessário o passado para viver o futuro. Toda a poesia e desejos de transformação derivam de um futuro em aberto. 0 meu projeto como historiadora é analisar o passado, mas o meu projeto como ser social é uma projeção de futuro!

No futuro que eu defendo não existe barbárie. Não é preciso barbárie para haver desenvolvimento, mas eu não posso fazer essa revisão histórica, até porque isso, em última análise, diminui as classes trabalhadoras, as mulheres, os setores oprimidos e os povos periféricos; são sempre vítimas, nunca são sujeitos, são sempre os vitimizados.

É o mesmo da relação com o feminismo, aliás, a mulher aparece sempre numa posição de vítima, nunca aparece como um sujeito complexo, multifacetado, singular. É uma espécie de realismo socialista, heróico-sentimental. Por exemplo, a mulher, se aparece como mãe retratada nos media é porque é mãe, cria-se um grande debate chamando preconceituosos, ai ai!. Bom, mas as mulheres não são mães? Nós também somos mães. Acho que nós temos de chegar a um estágio, muito desenvolvido da Humanidade, para sermos outro tipo de mães, que é não sermos só mães.

Há riscos, claro, hoje, nesta onda de feminismo ser dominada pelos desejos do Banco Mundial (BM) de incorporar força de trabalho feminina criando competição com os homens - justamente aquilo que estava mal antes vem agora reforçado na onda de feminismo. Um estudo publicado pelo BM calcula em 160,2 triliões de dólares as perdas de "capital humano por as mulheres não estarem plenamente incorporadas ao mercado de trabalho assalariado em muitos países" (Quentin WODON; Benedicte LEROY DE LA BRIERE, 2018, p. 2).

Cuidado com o que desejas, já diziam todos os contos infantis. Pode tornar-se realidade. Com a automação e mecanização, as mulheres podem fazer os trabalhos de homens, estar numa linha de montagem da indústria automóvel 8 horas seguidas, com uma pausa de 7 minutos. Ele ajuda com as crianças e ela vai para a linha de montagem, intensificação à escala global da exploração. Na ordem da acumulação de capital, as empresas querem lucro e o gênero desaparece para sermos todos trabalhadores plenamente alienados, inclusive alienados do corpo e do sexo. No mundo do capital, somos todos nem homens nem mulheres, mercadorias sem sexo ou gênero. O que é um absurdo, há diferenças entre nós que têm que ser respeitadas, igualdade é respeito pela diferença.

Agradeço que um homem me carregue a mala quando a tiro da cabine do avião, fico até ofendida quando não o fazem (e hoje quase nenhum homem o faz), porque ele tem mais força muscular; eu carregava no meu osso da anca os meus filhos gêmeos um de cada lado, com uma facilidade que quase nenhum homem consegue, apesar de eu ter duas hérnias discais, aquele osso é parte da anatomia da maioria das mulheres. Uma coisa é o respeito - integral, sem exceções - pelos direitos sexuais, sou a favor de todos, outra é querer dizer que não há sexo, é absurdo. E perigoso, há um mercado de mudança de sexo, com muitos arrependidos que não puderam voltar atrás, por exemplo, mas nem sequer há uma reflexão sobre as nossas relações sociais mais amplas. Um casal hétero ou gay com filhos, numa grande metrópole, vive hoje uma vida de inferno se viver do trabalho, trabalha na realidade 10 horas, passa 4 em transportes, e a seguir tem que cuidar dos filhos e da casa, mesmo que partilhe tarefas, a vida é um inferno, para todos. Isso o BM não se lembra de estudar [risos irónicos], os horários efetivos de trabalho real, a necessidade do Estado Social etc. 
A esquerda aderiu a esta marginalidade em peso. Há uns meses, em Porto Alegre, uma professora dirigente sindical, por acaso mulher negra - parecia um script encomendado, disseme, em público, aliás, que era dirigente dos professores e numa reunião estiveram duas horas a discutir se devia haver uma casa de banho trans, e não conseguiram definir a pauta de luta contra os ataques trabalhistas. No mundo do capital perfeito, só vai haver uma casa de banho, a do trabalhador mercadoria. E a esquerda caiu nesta casca de banana como um patinho ingénuo. Pior: a direita aparece agora como campeã da liberdade de expressão e do bom senso. É terrível. Até nos calamos com denúncias públicas que transformaram algumas universidades em espaços aberrantes de perseguição a professores, onde todos desconfiam de todos, com murais públicos de denúncias! Conheço professoras mulheres que toda a vida lutaram por direitos acusadas de racismo porque exigiram mais trabalho a alunos negros para melhorarem as avaliações porque sabiam pouco, homens muito decentes acusados de abuso sexual porque as mulheres quiseram vingar-se. E tudo isto sem julgamentos ou advogados, é terrível, como nos podemos calar? E direitos processuais e jurídicos, não há?

Quando esta onda de denúncias sem olhar a meios tiver um fim, vai ser triste de ver; a reação dos homens enraivecidos e injustiçados, a direita a cavalgar o princípio da inversão do ónus da prova e a não presunção de inocência, como nos EUA, em que não há investigação e julgamentos com defesa pública, mas apenas shows televisivos com denúncias, quando tudo isto for dirigido contra os sindicalistas e revolucionários e intelectuais críticos, quando a direita vier dizer aos trabalhadores organizados "agora vão provar do veneno" da ausência de respeito pelas leis processuais, onde isto tudo vai parar?

A desigualdade entre sexos/género ou de etnia é um assunto tremendamente grave, não pode ser tratado com esta leviandade. É a defesa das mulheres e dos oprimidos que está em causa, não pode ser o vale tudo. No outro dia disseram a um colega meu emérito, um tipo que escreveu livros sobre igualdade de gênero quando não era moda, fez a tese sobre o tema há 40 anos, ninguém o fazia em Portugal, disseram-lhe, no Brasil, que ele não podia falar de racismo porque era branco. Patético! O que une a extrema-direita na Áustria, no Brasil e nos EUA não é a imigração, xenofobia, favelas, são todos casos diferentes, o que os une e lhes dá força é a derrota de um programa de esquerda universal e transformador, radicalmente reformadora que ofereça um programa de vida decente e feliz para toda a humanidade. A derrota sangrenta das primaveras árabes, o catatonismo dos novos partidos como o Syrisa ou Podemos, o caos na Síria, a destruição da Venezuela, sem revolução e sem governo; estamos a pagar um preço altíssimo...

A isto junta-se o risco sério de uma onda conservadora de retorno ao lar, à família nuclear, como espaço supremo da felicidade, em que o homem é chamado a dividir esse espaço em vez de ambos, homem e mulher, conquistarem, pela redução do horário de trabalho e o Estado Social, a esfera pública.

Por exemplo, eu penso que, hoje, um dos maiores retrocessos da Humanidade, e que o feminismo não quer enfrentar, é que uma boa parte das mulheres do mundo tem como o projeto de vida mais feliz das suas vidas ser mãe. $E$ isso tem a ver com dois fenômenos, o que é o trabalho e o que não é a política. A perda de centralidade do trabalho criador, a degradação das condições de trabalho e vida, e as expetativas declinantes na esfera pública tornaram o lar o suprassumo da paz, o ninho que nos tira da guerra civil em que se transformou a sociedade. As mulheres não se reveem - nem as mulheres nem os homens! - no projeto de trabalho como protoforma criadora - e emancipadora.

O trabalho não é nada criativo, porque é padronizado pelo capital. E não é emancipador, porque ele não é um palco coletivo de luta política e de luta sindical, ele é um palco de subjugação permanente; os partidos, os sindicatos ou a mídia não existem, ou então são gestores do status quo com mais ou menos boas intenções.

E o retorno ao núcleo familiar restrito como único projeto é um retrocesso profundo, porque não há nada mais des-sexualizante do que passar um dia no trabalho, duas horas no metrô e ônibus, cozinhar, estender roupa, ajudar os filhos nos TPC e a seguir vamos quê, fazer amor? A maioria dos casais, na verdade, vai gerindo a vida em comum, com muita civilidade, aturam-se, não se desejam, querem ou emocionam. Até inventaram a teoria de que a paixão morre naturalmente. O que "mata naturalmente" é a vida competitiva em sociedade. A vida do núcleo familiar moderna, urbana, sem apoio, é insuportável. Muitos resolveram isso vivendo sozinhos e com animais. Mas o que nós temos é que mudar o modo de vida, reduzir o trabalho, lutar, transformar, viver sem medo, com segurança económica, direito à saúde - não há paz na escassez e no medo -, ter serviços coletivos e restaurantes públicos, lavandarias públicas, socializar o trabalho doméstico e viver intensamente a vida; aí sim, viver intensamente e com paixão a vida com os nossos maridos, mulheres, filhos, amigos. O trabalho no capitalismo está a destruir-nos como seres humanos plenos.

Ora, os sindicatos e partidos que são hoje sobretudo dirigidos ainda por homens podem ter um papel construtor nisto; os homens têm que perceber que, por terem mais força física ou poder, 
devem proteger as mulheres, não as ver como inimigas que vão roubar-lhes o lugar de trabalho ou colocá-los a lavar loiça. Se o Estado não tem creches, faça-as o sindicato; se uma mulher é perseguida, tomem a decisão de ir ter com o perseguidor e não o permitir; se uma mulher entra de novo no trabalho, lutem com ela e por ela por salário igual. Não é possível que uma mulher se sinta mais segura em ir denunciar um caso de assédio ao patráo do que ao sindicato! $O$ sindicato tem que proteger as mulheres. Proteger não é criar a possibilidade de lançar o caos da denúncia pública e da desconfiança generalizada! Mas tem que proteger!

E as mulheres têm que deixar o "papel" de vítima, e ir para a frente dos sindicatos e partidos de esquerda e dirigi-los, em vez de só dirigirem grupos de mulheres dentro dos partidos. Dirigiam o conjunto das organizações e não a secção feminina das organizações. Têm que ter um papel de direção da sociedade como um todo e não só das questões ditas femininas. Precisamos de mais Rosas Luxemburgo.

Outra coisa: os nossos filhos são realmente emocionalmente muito intensos e muito apaixonantes, mas são as relações de dependência. Uma boa relação de sucesso com os nossos filhos leva à sua independência, não leva à eterna dependência económica, afetiva etc. Portanto, nós devemos ficar felizes quando os nossos filhos saem de casa, o que não quer dizer que não se tenha relações maravilhosas com os nossos filhos. Mas quando os nossos filhos saem de casa e ganham autonomia, esse é o momento em que nós temos de ficar felizes, não é o momento em que eles gatinham e balbuciam coisas mimosas, isso é nós nos revermos enquanto seres felizes nos nossos instintos animais, protetores, primitivos.

Qual é o nosso instinto animal? Nós temos um instinto animal para a adoção de crianças, bebés... Os bebés são superatrativos, os bebés dos mamíferos em geral e, portanto, todos são irresistíveis!, são física e gestualmente irresistíveis; selecionados para serem assim. Isso é o nosso grande momento? Nosso ápice de felicidade? Isso, sim, parece-me um tema que homens e mulheres - não é só uma questão feminina, veja bem - deviam colocar em cima da mesa: é o retrocesso à família nuclear, restrita. Eu sou pessoalmente altamente familiar, mas será o retorno à família algo do espaço e suprassumo da felicidade humana?

SAF: Como descreveria a sua trajetória académica até o seu ingresso no Instituto de História Contemporânea, da Universidade Nova de Lisboa?

RCV: Eu fui para Direito, que foi um enorme erro!, por pressão familiar. Estive lá até o terceiro ano. Como eu odiava estudar Direito! Eu ia fazendo as cadeiras com uma nota média, quer dizer, e dedicava toda a minha vida então a ler romances, o que foi fundamental para a minha formação integral como historiadora e como pessoa, a todos os níveis. Para a escrita, também. Portanto, eu hoje em dia acho que os anos em Direito não foram anos perdidos, porque foram anos dedicados à literatura e eu aprendi mais História na literatura do que em qualquer outro livro. Também foi quando li os clássicos marxistas.

Há, quiçá, três grandes coordenadas da formação histórica em minha vida, creio eu. O marxismo clássico (e não o académico) da geração de Marx e Engels, passando por Labriola e Plekhanov até a geração de Leon Trotsky e Rosa Luxemburgo. Os romances, a literatura - toda ela, da literatura dita de esquerda ou o que seria hoje considerado de esquerda, como Zola, a uma literatura de direita, como o Balzac (tal como Marx, adoro Balzac!) ou Vargas Llosa. Adoro literatura; a boa literatura é um retrato implacável das nossas grandezas e misérias. E depois, a minha formação académica na Holanda foi muito importante; a História Global do Trabalho e o rigor das fontes na criação de equipas dos projetos internacionais, tudo isso foi muito, muito importante. Também foi um processo de internacionalização, muito rico, sempre. Portanto, diria que estas três componentes são absolutamente fundamentais. A minha curta passagem por partidos políticos foi importante, mas é sempre contraditória - é um palco fundamental de formação teórica. Os meus melhores alunos de pós-graduação que tiveram melhores notas em júris públicos (não marxistas, aliás) passaram por partidos marxistas, não é exclusivo, claro, mas é um dado importante. Não se ignore o que aprendemos aí. Porém, os partidos tendem a promover mecanismos de autocensura que bloqueiam a reflexão - o seu instintivo de sobrevivência, a escassez de meios e quadros, rodeados de inimigos, tende à criação de um aparato onde o dissenso só é permitido quando não abala a estrutura. Sobre isto não conheço exceções. Não há liberdade de pensamento dentro de partidos políticos hoje; o medo impera, mais nuns do que noutros, claro. Por isso, nunca me disciplinei a nenhum partido, sinto-me sempre sufocada, coibida. Há mecanismos manipulatórios subtis de sufoco que vão desde a coação explícita - impedir uma publicação - até a manipulação infantil, calúnia, romper amizades, olhar de lado... Sempre me disseram que eu não era disciplinada; ora, eu sou próximo do doentio em matéria de disciplina e compromisso. Tenho na minha agenda horas definidas até para ler aos meus filhos, que já são grandes, namorar, e tempo definido na minha agenda para ler e pensar como seduzir o meu marido; é verdade, estudo tudo, dias para artigos, horas para escrever, horas para cultivar a paixão (e depois não virem dizer que morreu pelas rotinas) [risos] - ele, 
felizmente, é mais saudável e desfaz tudo isto com humor e somos dois amantes apaixonados com muito improviso. Ora, no campo do trabalho e social sou ainda pior, sou prussiana, nas palavras do meu marido, sou capaz de sair de casa à meia-noite para ajudar um sindicato ou uma causa social, e não me deito com um talher por pôr na máquina! Engoli o saber de uma avó camponesa: "não deixes para amanhã o que deves fazer hoje"; o que não suporto é disciplinar-me à balda, à ausência de rumo e à falta de compromisso e estratégia. Há reuniões de esquerda que são uma experiência psicanalítica de total loucura - todos falam sobre nada por horas. E centenas de quadros afastaram-se porque não aguentam tanta perda de tempo, não é só política... Ou melhor, é política. Se há coisa que aprendi na minha investigação sobre História do movimento operário é que há sempre uma simbiose entre política e organização, uma determinada organização serve uma determinada política, a forma é parte do conteúdo e vice-versa.

É triste. Temos que mudar! Porque, na verdade, o que mais precisamos hoje é de um partido. Sem partidos assim vamos sucumbir. Militar hoje num partido é um dever para com a Humanidade. Mas temos que reinventar os partidos. Perder o medo de nós próprios; sem isso, sem a radical crítica de nós próprios, em total liberdade, não vamos a lado nenhum. Os partidos impedem de facto o dissenso dos intelectuais, mas aturam horas de discursos vazios e lunáticos da sua base social.

O Direito, voltemos lá, à minha formação. O Direito (em Coimbra) foi muito importante porque eu não estudei direito, eu fui ler literatura e militar contra o pagamento de taxas na Faculdade e isso foi fundamental - digo isto sem qualquer ironia! E depois fui para o ISCTE, onde fiz o doutoramento. No ISCTE fui a melhor aluna do curso de História, aí já tinha notas muito boas porque era apaixonada pelo que fazia, era muito disciplinada, dedicada, atenta. Ainda hoje eu tenho os meus apontamentos da faculdade, que são incríveis! Quer dizer, olho e penso "realmente, a dedicação que eu dei aos estudos". Eu era muito apaixonada e sou pela História e o meu ofício. Nota-se pela meticulosidade das notas, referências, caligrafia, organização. Depois, eu fiz o doutoramento, na História do PCP na Revolução dos Cravos e, ao estudar um partido político, eu quis estudar a revolução social e foi por isso que eu comecei a dedicar-me à História social do movimento operário, e à História do mundo do trabalho.

SAF: É interessante dizer isso em relação à literatura, porque Carlo Ginzburg (1999), quando Ihe perguntam numa entrevista o que recomendaria a um jovem historiador, responde: "ler romances, muitos romances".

RCV: Por exemplo, o caso dos romances russos do século XIX - quer dizer, o que eu aprendi com Tolstói, com Dostoievsky, mais tarde com Nabokov e muitos outros... Toda a literatura russa clássica é uma coisa fantástica, não é? De facto, a minha melhor fonte para a História da servidão na Rússia é o Tolstói - e não o Trotsky. Eu sou uma leitora entusiasta e dedicada da obra de Trotsky, inclusive como escritor, não é à toa que o seu apelido era 'A Pena'. Mas há melhor do que Gogol para descrever a servidão e a corrupção da Rússia decadente?!

Por fim... é preciso viajar para o desconhecido, morar fora do país, e engajar-se de facto. Sobretudo, eu diria que é preciso se apaixonar - profundamente - pelo gênero humano.

\section{SAF: Quais os maiores desafios que encontra como mulher na Academia?}

RCV: Nunca me senti ameaçada, diminuída ou agraciada por ser mulher. Nada disso. No meu percurso académico, nunca senti a questão de gênero neste sentido. Há outras questões que são fortíssimas, outras distintas, que têm a ver com a competição doentia, com o produtivismo irracional, a organização hierárquica dos locais de trabalho... Sinto que uma das coisas mais destrutivas para as pessoas é o assédio moral. E está disseminado em todos os locais de trabalho. Mas veja, isso era uma coisa típica de abuso de poder hierárquico e não tem nada a ver com assédio sexual.

Eu nunca notei nem benefícios nem malefícios pela minha condição de ser mulher. Acho é que a Academia é um palco de inveja doentio. Eu nunca conheci um ambiente onde a inveja fosse um sentimento tão disseminado como a Academia. Para mim foi, de longe, o pior ambiente de trabalho que eu conheci; e eu conheço muitos, enquanto investigadora. Muitos. A Academia foi, de longe, o pior. Tem a ver com a competição, com a fragilidade dos intelectuais... Os intelectuais são muito frágeis! A separação entre o trabalho manual e intelectual faz mal à saúde psíquica... é curioso. Eu penso que é Gramsci que diz que os operários e camponeses sobreviviam muito melhor no cárcere do que intelectuais, porque a separação da natureza nos intelectuais é muito superior. Por exemplo, a facilidade que um trabalhador manual tem, dentro da prisão, de saber as horas do dia é muito superior à de um trabalhador intelectual. Não sei se é isso que faz com que os intelectuais sejam tão carcomidos pela inveja, mas não são bem intelectuais, devo dizer, o exemplo não é bom... São os académicos. Até porque há 
muitos intelectuais fora da Academia e muitos académicos/universitários que não são sequer intelectuais profissionais. Aliás, há muito poucos intelectuais, em geral. Gente com capacidade de pensar livremente e de agir para transformar o pensamento e a ação é rara! E a maioria dos que conheci não estava na Academia. Conheci alguns na Academia. A maioria dos que conheci estava nos partidos políticos.

SAF: As suas visões e opiniões encontram, ainda, um palco alargado em meios de comunicação social. Podemos vê-la semanalmente no programa "O Último Apaga a Luz" (RTP), que vai já na terceira temporada, e tem aparecido regularmente na televisão e na rádio, para debater vários temas, em vários veículos. Neste sentido, qual a importância da participação frequente de uma historiadora em debates inseridos em programas de televisão de grande audiência?

RCV: Porque a visão histórica permite desnaturalizar muitos comportamentos políticos e situações sociais, e permite também compreender aquilo que é essencial; que o homem é ator da sua própria história. Nós não somos regidos permanentemente por uma mão invisível ou por um Deus natural que controla os nossos movimentos. Hoje, essencialmente, aquilo que é fundamental ao longo da nossa vida está sob o nosso domínio. Há ainda doenças que não são controláveis, há um tempo de vida limitado, mas... todo o resto... Nós temos hoje um domínio sobre a natureza para construir uma sociedade igual e livre para toda a Humanidade que é gigantesco. E, portanto, a História é histórica; está nas nossas mãos mudar o mundo. E isso é uma noção que a História nos dá. Ou seja, o poder dos Homens, e o poder da Humanidade. E é importantíssimo para as pessoas desnaturalizarem comportamentos, muitas coisas hoje que são banais para as pessoas ou que as pessoas acham que são naturais não o são; não eram assim há cinquenta ou há cem anos. Para o bem e para o mal. É preciso compreender que nós conseguimos dominar, conseguimos dirigir, conseguimos construir e destruir relações sociais. Isso é o espetro da autodeterminação. E é muito importante construirmos intelectuais públicos para além das linhas de forças da socialdemocracia e do liberalismo. Como historiadora pública, que lida com públicos, que escreve livros de ampla divulgação, que fala a língua corrente do cotidiano, que traz questões públicas e problemas humanos ao centro do debate, creio que é muito, muito, muito importante nunca ter de escolher entre pesquisa e extensão, ciência e política. Sem perder o tino do compromisso com todo o rigor disciplinar das ciências sociais e humanas, mas sem abdicar da comunicação mais ampla, que vai mais longe, e que toca as pessoas. Oxalá floresçam centenas de intelectuais públicos interessados no mundo do trabalho e da vida. Portugal bem poderia se beneficiar.

SAF: "A liberdade das mulheres é um sinal da liberdade social" - para Rosa Luxemburgo, a questão da emancipação das mulheres era, pois, indissociável da luta da classe operária como um todo. Já no início da década de 1970, no livro A Mulher Eunuco, Germaine Greer (1970) insiste na centralidade da sexualidade para as questões feministas. Em Portugal, a Revolução de 1974 foi também determinante para a afirmação dos direitos das mulheres, marcando um passo sem precedentes para a igualdade, pelo menos em termos jurídicos. É importante referir, por exemplo, que até 1975 os 'crimes de honra' estavam previstos pelo Código Penal português, ou seja, um homem podia matar a esposa ou as filhas menores de 21 anos se se considerasse por elas desonrado, tendo uma pena de apenas 6 meses de desterro da comarca. Até 1975, também, e salvo situações excecionais, as mulheres não podiam votar. Precisavam de autorização marital para viajar. Resumindo, até a revolução e todas as mudanças promovidas no pós-25 de Abril, legalmente e na prática, uma mulher dependia do seu marido e ele tinha sobre ela o poder e o direito de fazer virtualmente tudo. Isto para não falar dos 40 anos de ideologia salazarista - Deus, Pátria e Família - que tinha como um dos seus slogans "a mulher para o lar". Posto isto, quais considera terem sido os grandes legados do 25 de Abril para o movimento feminista em Portugal e de que forma este terá conseguido acompanhar, factual e ideologicamente, as reivindicações de outros movimentos feministas do Ocidente?

RCV: É uma pergunta interessante. Primeiro, deixe-me fazer uma pequena correção: a legalidade de muitos desses crimes termina em 1975, mas já tinha terminado em '74, ou seja, as mulheres passaram a votar nos locais de trabalho e a determinar os locais de trabalho, como hoje não determinam. As mulheres e os homens - e a frase da Rosa Luxemburgo faz todo o sentido aí - foram mais livres em 1974 e '75 do que são hoje. Eles determinavam as suas chefias, a sua organização do trabalho, o seu tempo de trabalho, o seu tempo de vida, por meio da democracia direta. Tiveram mais liberdade em '74 e '75 do que têm hoje. Essa liberdade foi progressivamente sendo perdida, para homens e para mulheres, a partir de '76. Foi restringida a liberdade; a liberdade foi cada vez mais a liberdade circunscrita aos direitos políticos e legais formais, e menos liberdade económica. E sem liberdade económica não há liberdade alguma. Também não há liberdade sem liberdade cívica e política, mas veja: as mulheres legalmente 
só votaram em 1975, mas no dia 25 de Abril, ou 26 ou 27, estavam todas a votar nas comissões de trabalhadores, por aquilo que era essencial à sua vida; estavam a votar que iam sair às $X$ horas do trabalho e estavam a votar que uma casa desocupada ou ociosa ia passar a ser uma creche, estavam a votar que... alguém ia ficar a tomar conta dos seus filhos.

O legado do 25 de Abril não é um legado: é o 25 de Abril em 1974-75. Em 1976, a contrarrevolução vai diminuir substancialmente as liberdades económicas porque ela diminui a segurança. Nós hoje temos liberdade para amar quem queremos, mas não temos dinheiro. Há uma percentagem dos casais portugueses que está junto porque tem uma hipoteca de casa, não tem liberdade para amar. Hoje, uma parte das mulheres, em teoria, pode amar quem quiser, mas isso não existe na prática, porque ela não tem emprego nem tem como dividir a casa com o marido. Ela tem proteção jurídica para não ser violentada pelo marido, tem; mas não tem liberdade para chegar a casa e ir namorar ou ver um filme ou descansar. Se ela chega a casa e tem filhos, tem de ir cuidar dos filhos e, a seguir, 'está morta', vai dormir.

São quatro paredes caiadas e um cheirinho a alecrim, não é? Outra vez prisão domiciliar, uma prisão sem grades, mas, ainda assim, uma prisão.

Portanto, nós temos aqui um problema seríssimo, que é: uma parte das mulheres bem minoritária em Portugal tem muita liberdade (nas quais eu me incluo), porque tem dinheiro. Se não tiver dinheiro, não tem liberdade. Porque não tem como pagar amas, empregadas domésticas, e é uma escrava do trabalho para o lar... Portanto, isso é um problema hoje; para mim, hoje, a frase da Rosa Luxemburgo faz mais sentido do que nunca. A menos que se seja solteiro, estudante, ou tenha um rendimento muito acima da média - e acima da média é acima de $80 \%$ da força de trabalho -, a nossa vida está inteiramente dedicada ou ao trabalho assalariado ou ao trabalho de reprodução social. Porque o Estado só toma conta das crianças enquanto nós estamos no trabalho, não é depois. Não há lavandarias públicas, com as quais a Alexandra Kollontai sonhava, nem restaurantes coletivos. É óbvio que eu devia chegar a casa e ter um restaurante coletivo público no bairro (com excelente comida, claro), do Estado, onde fosse jantar com os meus filhos, em vez de ir cozinhar todos os dias, até porque, do ponto de vista da produtividade, isso é uma loucura, cada família a cozinhar todos os dias? Para si só? Desperdício, irracionalidade, perda de tempo, tudo errado! Claro que, se me apetece cozinhar um dia, cozinho na minha casa para amigos; outra coisa é todos os dias isso! Ninguém aguenta, ninguém gosta. E cozinhar sem prazer é como amar sem paixão. Sabe mal para quem come e para quem faz.

A socialização do trabalho doméstico vai aumentar exponencialmente a felicidade geral de todos porque, neste momento, uma família regular, que tenha filhos, passa quatro horas por dia no trabalho doméstico. É um avanço que deixe de ser a mulher e passe a ser também o homem; são duas horas para cada um. Sim, é um avanço pequenino, mas ninguém vai fazer amor depois de duas horas a limpar pratos e a fazer camas e a educar filhos! Portanto, a nossa liberdade está posta em causa, porque o desenvolvimento social das forças produtivas e da produtividade é concentrada nos lucros, e não em reduzir o horário de trabalho e aumentar o bem-estar social das pessoas. Devo dizer que essas ideias antediluvianas, do socialismo primício, pré-marxista, a utopia dos falanstérios e todo o mais, nisso eu me revejo muito mais do que no feminismo dominante - neoliberal e pós-moderno. Charles Fourier, entre outros, entendeu a reinvenção do cotidiano - sem isso não há luta pelo socialismo nem pela igualdade.

SAF: Hoje em dia, os debates acerca da igualdade entre mulheres e homens nas mais variadas áreas da vida pública e privada têm se alargado a outros públicos e a outros meios e plataformas. As notícias, informações, opiniões estão à distância de um clique. Ao contrário do que seria de esperar, a acessibilidade do debate aparenta ser um dos fatores para o extremar e para fragmentar as visões acerca do que é - mas, sobretudo, do que não é - o feminismo. Numa de suas intervenções no programa "O Último Apaga a Luz", de 22 de dezembro de 2017, a propósito da posição de Camille Paglia - intelectual ítalo-americana - quanto à nova onda de feminismo nos Estados Unidos, disse que não se revia no feminismo dominante, que este não a representava. Tem sido comprovado em alguns países que a maioria das mulheres pode concordar com os ideais fundamentais do feminismo sem que isso signifique necessariamente que se considere 'feminista'. Na sua opinião, por que razão isto se tem verificado?

RCV: Eu acho que há um feminismo, hoje em dia, completamente contraproducente, é um feminismo pós-moderno e contra a ideia de classe. É justamente um feminismo movido a ódio contra os homens. No Maio de '68 nós lutávamos por a mulher sair de casa e conquistar 0 espaço público. Hoje em dia, uma parte das feministas luta por trazer os homens para casa e, juntinhos, irem lavar a loiça; isso é... é um retrocesso gigantesco do ponto de vista da evolução, quer dizer, da socialização do trabalho reprodutivo, o cuidado coletivo das crianças, da vida doméstica etc. desapareceu; portanto, agora o sonho é "vamos ficar em casa todos juntos, vamos lavar loiça juntos, vamos fazer as camas juntos" e, claro!, depois os casais odeiam-se, 
porque não têm vida própria, não têm espaço para amar, não têm espaço para si próprios e vê-se um retrocesso imenso.

Agora, essa visão não é despolitizada, é uma visão do capitalismo, é uma visão do BM, que diz que é preciso concorrência do mercado de trabalho à escassez de força de trabalho, precisamos de trazer as mulheres, nomeadamente em países como a Índia, os EUA, o Brasil etc. etc., onde havia grandes contingentes de trabalho social feminino não assalariado ou em part-time; precisamos de trazê-las para o mercado de trabalho. Nesses países, onde há muita violência machista, e pouco Estado Social, é impossível trazer as mulheres para o mercado de trabalho se não se controla a violência e, por isso, a própria burguesia está contra a violência e faz propaganda contra a violência. Mas Estado Social não fazem. Sem ele, há guerra dos sexos, quem vai lavar a loiça? As melhores campanhas publicitárias contra a violência de gênero vêm dos Estados capitalistas e os jornais mainstream todos os dias trazem uma denúncia de assédio contra um homem. Ainda bem, desse ponto de vista! É óbvio que nós temos de ser contra a violência. Agora, isto podia ser aproveitado pelas feministas para dizer o seguinte: "o capitalismo tem escassez de força de trabalho, as mulheres vão entrar no mercado de trabalho em concorrência com os homens, então vamos juntos todos lutar por melhorias de salários". Não, as mulheres estão a aceitar uma direção política que as leva a entrar no mercado de trabalho e a dizer "o meu inimigo és tu, que ganhas mais; tu não és o meu amigo, com quem eu vou fazer uma greve e juntos vamos lutar os dois por eu ter o mesmo salário que tu". Não, é: "sai daí, dá-me a quota do teu salário". Portanto, isso é o contrário da solidariedade, isso é competição, é expansão da taxa de lucro e da acumulação capitalista. Ainda recentemente foram publicadas no BM duas investigadoras de ponta a dizer isso mesmo: "precisamos de aumentar a produtividade, precisamos de trazer as mulheres para o mercado de trabalho, todos vamos ganhar com isso". Todos não. Obviamente que o que se está aqui mesmo a aumentar é a competição e o lucro.

Da mesma maneira que eu sou contra homens que não querem as mulheres nas suas fábricas porque elas vão ser concorrentes, também sou contra mulheres que querem entrar nas empresas e, em vez de dizer "vamos lutar juntos", dizem "eu quero a tua quota". Quota? De mulheres? Nós não queremos quotas, nós não lutamos por quotas; nós lutamos pela igualdade, é um valor superior a nós! O possibilismo é um mal. Portanto, todas as nossas estratégias têm de ser estratégias combinadas, e de unidade, dos trabalhadores manuais e/ou intelectuais.

Se as mulheres vão entrar nas empresas, então que reduzam o horário de trabalho para toda a gente, sem redução salarial, em vez de dizer "sai daí da frente tu que ganhas dois mil que é para a mulher entrar a ganhar mil e quinhentos e assim baixa-se o salário de toda a gente". É o modelo de Hollywood! O que é o modelo de Hollywood? O Kevin Spacey, que ganha vinte vezes mais, é demitido, é substituído, a mulher que entra à frente dele ganhava um décimo, passa a ganhar dois décimos e a partir do salário dessa mulher equalizam-se todos os salários... para baixo, todos! Bom, Hollywood é um caso que não me preocupa, nem interessa, como deve imaginar. Quanto é que eles ganham em Hollywood é uma coisa que não ocupa os meus dias, mas esse modelo é o modelo das empresas: é tirar o tipo que ganha dois mil, pôr a mulher a ganhar mil e duzentos e dizer "então, vamos todos ganhar como as mulheres".

Os sindicatos têm responsabilidade nisto, porque eles próprios têm que ir ter com as mulheres e dizer "ok, há escassez de força de trabalho, vamos lutar juntos". Os sindicatos também têm tendência a fechar-se e a dizer "aqui ninguém entra". Um bom exemplo seria o do Sindicato dos Estivadores face aos trabalhadores precários. O que eles fizeram face aos trabalhadores precários deviam todos os sindicatos fazer em relação à entrada das mulheres no mercado de trabalho: "nós, trabalhadores fixos, que já cá estamos, vamos quotizar para uma luta comum para que vocês entrem com o mesmo salário que o nosso". Não é "para que vocês entrem com quotas". Quotas significa, sabe-se, gerir a competição capitalista dentro do capitalismo, não significa melhorar o salário de todos; significa, de facto, garantir que uns vão estar em competição com outros. Contra a fórmula de quotas de gênero, a política de quotas do sindicato. As palavras são mesmo fabulosas, não é? Pode-se dizer o mesmo e o contrário...

SAF: $E$ em relação à competição entre mulheres, nomeadamente às críticas feitas ao 'White Feminism'. Acha que também é preocupante, ou partindo do princípio de que o feminismo é uma questão de trabalho, esse tipo de divisão se dissipa?

RCV: Antes de mais nada, como eu já o disse, o primeiro impulso deste movimento feminista mundial é a necessidade face à escassez de força de trabalho de incorporar força de trabalho feminina, sobretudo em países onde, pelas sociedades escravocratas e coloniais ou segregadas, se permitia trabalho doméstico muito barato, que é o caso do Brasil, dos EUA, e de outros, ou sociedades muito rurais, como é o caso da Índia - as mulheres não estavam incorporadas ao mercado de trabalho assalariado na totalidade. Portugal está há muito por causa da guerra 
colonial e da imigração. Há uma onda de feminismo mundial, porque há uma onda mundial de a burguesia incorporar as mulheres a um novo mercado de trabalho.

A segunda coisa é que isso vem acompanhado por uma direção política, que é a ONU, que é o BM, de competição. Depois, a partir daí, há uma série de grupos oportunistas, académicos, que vão criando as suas próprias linhas - eu conheço-as todas, não estou a desvalorizar; são coisas muito elaboradas, sofisticadas, mas sem qualquer interesse para a sociedade! Não tem qualquer interesse para a sociedade perceber se é uma feminista branca ou se é uma feminista negra, se é feminista brasileira, se é feminista da Escandinávia; esse é um debate que a mim não me interessa nada e estou a dizê-lo com muita frontalidade! A mim interessa-me perceber como é que as pessoas têm projetos de sociedade, não é de si próprios e dos seus grupos particulares. "Qual é o nosso melhor projeto para vivermos bem, juntos?"; essa é uma pergunta que a gente tem que fazer à sociedade e dar-lhe uma resposta. Obviamente que, enquanto existir lucro, nós não conseguimos, e também lhe digo, hoje em dia, com as crises de identidade... Há pouco tempo, um intelectual em França publicou um livro em que dizia "bem, eu não tenho vergonha de dizer que sou gay, eu tive vergonha foi de dizer que era da classe trabalhadora", nem imagina a vergonha que ele teria se dissesse que era desempregado! A maioria dos desempregados, via de regra, nem sequer se assume como desempregado.

Nós temos um problema de falta de sentido de pertença da classe trabalhadora, não é qualquer falta de outras identidades particulares; temos excesso de particularismos, de individualismos, e falta de universalismo! Há imensos problemas na nossa vida íntima que, se nós não resolvermos os problemas da sociedade, nós não vamos resolver os nossos! É rolar pedras montanha acima e depois rock'n'roll, abaixo outra vez!

Como é que se pode olhar para um homem e dizer "é um machista, porque trabalha na fábrica e eu estou em casa?". Mas alguém acha que um homem depois de dezesseis horas de turnos chega a casa e vai tomar conta dos filhos?

E vou lhe dizer uma coisa, só uma intelectual académica de classe média universitária é que pode dizer isso, porque uma operária jamais vai ter coragem de olhar para o marido, que esteve dezesseis horas numa linha de montagem e dizer o disparate tresloucado: "agora, vem cuidar dos filhos".

O feminismo esquece-se de que, enquanto as mulheres estavam em casa, restritas à esfera privada, a cuidar da casa, os homens estavam em profissões infinitamente mais perigosas e penosas do ponto de vista físico. É uma desgraça, para mim é, a última coisa que eu quero é mulheres em casa!!! Portanto, por isso é que nós precisamos de uma forma de sociedade que retire as pessoas de casa, que retire as pessoas dos trabalhos penosos, que faça do trabalho um espaço de emancipação e criação e liberdade e que a casa não seja uma espécie de 'refúgio', sitiado, de uma sociedade em permanente guerra civil, porque, assim, a casa vai tornar-se um lugar insuportável! E deixe-me dizer com todas as letras: adoro minha família, adoro minha casa, cozinhar e rego as flores no jardim! Mas o núcleo familiar, restrito, fechado, irrespirável e acabrunhante, vai ser um lugar sufocante; nem sequer há liberdade sexual nesse caso. A liberdade sexual pressupõe a liberdade geral. Pressupõe que tenho liberdade de desistir de uma relação. Eu não tenho liberdade de desistir de uma relação se há uma dependência financeira real, quando são precisos dois salários para pagar a casa, e para aguentar-se os filhos. E isso é uma dependência financeira: o homem e a mulher têm a corda no pescoço. Precisamos reinventar o modo de vida e, para isso, precisamos transformar o modo de produção: um olho na luneta e o outro no microscópio. Parece-me que qualquer teoria crítica precisa dar conta disso tudo!

SAF: Mas, de facto, já que há pouco falou dos tribalismos, parece haver, cada vez mais, a tendência, ou a tentação, de fragmentar, ou rever permanentemente ideias e conceitos...

RCV: E nós nunca tivemos tanta possibilidade, na História da Humanidade, para ter uma visão internacionalista, universalista; a classe social trabalhadora, hoje, é uma classe trabalhadora que já incorporou massivamente os trabalhadores intelectuais que foram proletarizados, a divisão internacional do trabalho colocou-nos a todos no mesmo barco, do ponto de vista da globalização... Eu sei que se o salário da China desce, o meu salário aqui está ameaçado, portanto, a minha interdependência ficou mais clara em relação ao trabalhador chinês. Nós, culturalmente, temos capacidade de abraçar o mundo inteiro e viver nesta diversidade e promover esta diversidade maravilhosa, e o que é que fazemos? Não!, tu és branco, tu és europeu, tu és negro, tu já és negro do subúrbio, tu és negro do centro... E veja, digo-lhe sinceramente, eu vou a uma favela e os trabalhadores das favelas não querem ser favelados, nem acham muita graça à favela; querem é acabar com a favela e sair dali. Querem casa a sério com direito à cidade, equipamentos públicos, serviços, cultura. Uma operária não acha que o marido é terrível porque ele está dezesseis horas numa linha de montagem; acha que o marido está ali é a sacrificar a sua vida, o que é verdade! Portanto, é preciso ser académica 
e ter pouco tempo livre na vida para defender tais teorias. É preciso fechar-se com ou sem gabinete trancado ao que é a realidade lá fora.

SAF: Quanto à realidade portuguesa, quais considera serem os maiores desafios com que 0 feminismo hoje se depara?

RCV: Os baixos salários dos homens e das mulheres! Má qualidade de serviços sociais! Não há liberdade a sério quando não há segurança no emprego. A diferença salarial entre os homens e as mulheres em Portugal é de $18 \%$, entre o trabalhador fixo e o precário é de $40 \%$. Sem segurança no emprego não há vida. Nós não temos filhos por três meses, se não temos filhos por três meses, não podemos ter contratos por três meses! Nós vivemos a vida toda, tem que haver pleno emprego! Pleno emprego não significa a pessoa estar sempre no mesmo emprego, mas a pessoa tem que ter sempre direito ao emprego. O direito ao emprego tem que ter a dignidade do direito ao voto, não pode ser substituído pelo assistencialismo ou rendimento básico incondicional - a renda mínima - ou as pessoas receberem dinheiro.

Primeiro, o trabalho é um dever; se nós não somos doentes, nem idosos, nem crianças, devemos trabalhar, devemos contribuir para a sociedade com o trabalho. $O$ trabalho que existe tem que ser dividido por todos, e não devemos depender da assistência; devemos contribuir, viver com a dignidade do trabalho, reduzir os horários de trabalho e dar tal segurança às pessoas!

Portanto, o maior problema da sociedade portuguesa, a ameaça à vida e ao bem-estar português não é a divisão entre homens e mulheres, é a insegurança económica. Nós andámos anos a tentar dominar a natureza para vencer a insegurança. Quando chegámos à Revolução Industrial, e ao extraordinário desenvolvimento do capitalismo, face ao feudalismo, que é a possibilidade de ampliar o desenvolvimento das forças produtivas, garantindo abundância para todos, a propriedade concentra essa abundância nas mãos de uns poucos e, portanto, uma grande parcela da Humanidade hoje vive num estado de insegurança, por vezes, maior do que os camponeses, na época medieval ou até escravos...

SAF: Atualmente, como se encontra o campo de estudos da História das Mulheres e dos Feminismos em Portugal no que tange aos mundos do trabalho?

RCV: Eu acho que há um recorte muito fragmentado, muito fragmentário, muito identitário e, portanto, não se consegue compreender a essência dos problemas sociais. Nós passamos a vida a falar, por exemplo, das questões de gênero, da sexualidade... Eu gostava de saber se a maioria das pessoas vive bem e feliz a sua sexualidade e acho que isso não remete para o problema da diferença entre homens e mulheres ou à legalização dos casais homossexuais (de que eu sou a favor!). Isso remete a questões que têm a ver com coisas muito mais profundas; remete, aliás, à própria sobrevivência, ao instinto reprodutivo, à relação que nós temos com as doenças, que é uma relação de milhares de anos, de evitar, por um lado, consanguinidade, doenças infecciosas etc. Assuntos-tabus. Não foi só a lgreja que tornou o corpo um lugar de pecado; é a nossa própria relação com a natureza que nos coloca sistematicamente limites. Isso tornou-se muito óbvio com a AIDS, mas muito antes da AIDS, a Humanidade sempre se deparou com a relação com o outro ser também uma relação desse ponto de vista problemática. Justamente, nós hoje temos um desenvolvimento científico que nos permite controlar as doenças, controlar a natalidade e, portanto, isso veio aumentar exponencialmente a nossa possibilidade de liberdade de amar e a nossa relação com o corpo. Eu gostava que essas coisas fossem debatidas, em vez de apenas estar a lutar por as pessoas casarem. Eu, por exemplo, sou contra o casamento, também entre homens e mulheres. Sou contra o casamento! Por que é que as pessoas se hão de casar, e ter um papel assinado pelo Estado para dizer que se casaram? E eu sou monogâmica e casada, não careço de papel passado; não compreendo como é que a coisa mais libertária que a esquerda tem a dizer é o direito de determinados grupos, neste caso homossexuais, de verem o seu casamento reconhecido pelo Estado, quando toda minha vida quis foi que o Estado saísse dos casamentos!

SAF: A direita, ou, pelo menos, a lógica discursiva da direita, parece estar ganhando terreno no panorama político dos últimos anos - em 2016, Donald Trump foi eleito Presidente dos EUA; em 2017, Marine Le Pen chegou à segunda volta na corrida à Presidência da República em França, embora tenha perdido para Emmanuel Macron; e em 2018, Jair Bolsonaro foi eleito Presidente da República Federativa do Brasil. Enquanto portuguesa, como vê a ascensão política destas figuras, sobretudo do caso mais recente de Jair Bolsonaro, e quais considera serem as maiores implicações desta nova tendência política/ideológica para o futuro próximo?

RCV: A vitória de Bolsonaro tem vários significados. Evidentemente, a misoginia é indiscutível e visível. Mas a pergunta é: como combatê-la? O exército inimigo não se combate com palavras, 
ofensas e gritos ou denúncias de "fascista" e "machista". Isso supõe que as forças democráticas terão força e determinação para salvar o Brasil do fascismo e de tudo o que de mais obscuro acarreta, incluindo a misoginia. Penso que é no campo dos direitos sociais e na mobilização de base o único terreno onde poderá - digo, poderá - haver força para evitar uma tragédia.

SAF: Terminamos esta entrevista no ponto em que a começámos: seu mais recente livro, Breve História da Europa. A Europa dos poetas, a Europa dos cientistas, a Europa dos humanistas - a Europa da beleza e da justiça, do progresso e da felicidade, portanto - foi a mesma Europa onde se perpetraram crimes abjetos contra a humanidade. Sendo que, dentro da Europa, convivem muitas realidades e ideias diferentes, qual a ideia de uma Europa que julga ser unificadora e, possivelmente, reconciliadora dos seus povos, culturas/memórias e passados históricos? E, no contexto do projeto de uma Europa unida, quais considera serem os pilares em que este se alicerça atualmente enquanto conceito?

RCV: Eu penso que, se não houver uma Europa de povos, de trabalhadores manuais e intelectuais, contra o lucro, contra o setor financeiro - uma Europa que remete à beleza daquilo que foi o pós-revolução russa, antes de Stalin, dos Estados Unidos Socialistas da Europa e não esta união bancária e industrial de expansionismo alemão e protecionismo francês - a União Europeia de Maastricht está a caminhar para ter um papel ativo num novo conflito mundial. Já para nem falar no estado em que a União Europeia deixou os povos do Sul da Europa, depois da chamada crise das dívidas, em que Portugal e a Grécia se esvaíram dos quadros fundamentais para o seu desenvolvimento. E tem a ousadia, o descaramento e a xenofobia desvairada de falar em PIGS (Portugal-Ireland-Greece-Spain)! Não é por acaso que nós, europeus, ora não temos comboios e não temos médicos para fazer cirurgias; isso é a União Europeia. $E$, portanto, para construir uma Europa unida não é possível fazê-lo com a União Europeia, mas é essencial fazer uma Europa unida!

Nós não sobrevivemos sozinhos, nós somos europeus, nós temos que ter uma perspectiva absolutamente internacionalista e defender uma Europa unida. É maravilhoso fazer parte deste pequeno continente e destas gentes que também incluem muitas gentes que vêm de todo o globo: não existe Europa fechada em si mesma. A nossa concepção de Europa tem que ser a de uma Europa de povos, tem que ser uma Europa do mundo, tem que ser uma Europa internacionalista, sem dúvida alguma. Para se fazer esta nova Europa-do-trabalho-contrao-capital, temos de parar de embelezar o que é tão feio: a Europa da Troika, Bruxelas, dos capacetes azuis, do imperialismo, da guerra. Uma outra ideia de Europa deve começar por desautorizar as autoridades europeias que nem eleitas são na parte executiva. Veja: aquando da crise dos refugiados a Europa formal fechou suas portas, não foi assim?!? Mas a Europa real agarrou nos carros dos taxistas, estabeleceu pontes de solidariedade ativa e mostrou-se uma casamata avançada da História da Humanidade. Eu sou dessa Europa.

\section{Referências}

GREER, Germaine. A Mulher Eunuco. Circulo do livro, 1970.

GINZBURG, Carlo. "Una entrevista especial a Carlo Ginzburg: conversas com Adriano Sofri em 1982". Tradução de Carlos Antonio Aguirre Rojas. Prohistoria: historia, políticas de la historia 3 , p. 261-281, 1999.

VARELA, Raquel. Breve História da Europa - Da Grande Guerra Aos Nossos Dias. Lisboa: Bertrand, 2018.

WODON, Quentin T.; LEROY DE LA BRIERE, Benedicte. Unrealized potential: the high cost of gender inequality in earnings (English). The cost of gender inequality. Washington, D.C.: World Bank Group, 2018.

Sara de Athouguia Filipe (sara.deathouguia@eui.eu) é doutoranda no Departamento de História e Civilização do European University Institute. Suas áreas de investigação incluem História Cultural e Intelectual, História Política e Elites Políticas (séculos XIX-XX). Em 2016, Ihe foi conferido o grau de Mestre em Ciência Política pela Faculdade de Ciências Sociais e Humanas da Universidade Nova de Lisboa. 
COMO CITAR ESSE ARTIGO DE ACORDO COM AS NORMAS DA REVISTA

FILIPE, Sara de Athouguia. "Em direção a uma 'Europa do Mundo' unida: entrevista com a historiadora Raquel Varela". Revista Estudos Feministas, Florianópolis, v. 29, n. 1, e61883, 2021.

\section{CONTRIBUIÇĀO DE AUTORIA}

Não se aplica.

\section{FINANCIAMENTO}

Não se aplica.

\section{CONSENTIMENTO DE USO DE IMAGEM}

Não se aplica.

\section{APROVAÇĀO DE COMITÊ DE ÉTICA EM PESQUISA}

Não se aplica.

\section{CONFLITO DE INTERESSES}

Não se aplica.

\section{LICENÇA DE USO}

Este artigo está licenciado sob a Licença Creative Commons CC-BY 4.0 International. Com essa licença você pode compartilhar, adaptar, criar para qualquer fim, desde que atribua a autoria da obra.

\section{HISTÓRICO}

Recebida em 07/03/2019

Aceita em 03/04/2020

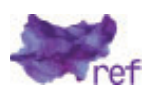

